\title{
Peran Kepala Sekolah Sebagai Leader dalam Meningkatkan Disiplin Kinerja Guru di SDN 02 Josenan Kota Madiun
}

\author{
Juarman $^{1}$, Nanda Nurrosyidah Rahmawati ${ }^{2}$, Dwi Lestari ${ }^{3}$ \\ 1,2,3 Pascasarjana Pendidikan Agama Islam Universitas Muhammadiyah Ponorogo \\ juarmanalfaraby@gmail.com \\ nandarahma32@gmail.com \\ tariloves99@gmail.com
}

\begin{abstract}
ABSTRAK
Artikel ini bertujuan untuk mengetahui bagaimana peran kepala sekolah sebagai leader dalam meningkatkan disiplin kinerja guru di SDN 02 Josenan Kota Madiun. Penelitian ini merupakan penelitian kualitatif model studi kasus dengan teknik pengumpulan data secara wawancara langsung, Analisis data dilakukan dengan mereduksi data, display data, dan mengambil kesimpulan. Adapun hasil dari penelitian ini menunjukan bahwa peran kepala sekolah sebagai leader dalam meningkatkan disiplin kinerja guru di SDN 02 Josenan Kota Madiun mengacu pada perannya untuk mewujudkan visi, misi, dan tujuan sekolah, mengembangkan inovasi, membangun motivasi kerja, melakukan komunikasi, menangani konflik, maupun mengambil keputusan.
\end{abstract}

Kata kunci: kepala sekolah, leader, disiplin kinerja

\begin{abstract}
This article aims to know how the role of headmaster as leader in improving the performance discipline of teachers at SDN 02 Josenan Kota Madiun. This research is a qualitative research model of case studies with data collection techniques in a live interview, data analysis is done by reducing data, display data, and taking conclusions. The result of this research shows that the role of the principal as leader in improving the performance discipline of teachers at SDN 02 Josenan Kota Madiun refers to its role to realize the vision, mission, and objectives of the school, develop innovations, build Work motivation, communication, conflict handling, and decision making.
\end{abstract}

Keywords:: headmaster, leader, teacher performance discipline

\section{PENDAHULUAN}

Dinamika pendidikan saat ini tidak lepas dari sebuah masalah. Salah satu masalah yang masih menjadi perbincangan hangat dikalangan dunia pendidikan yaitu masalah disiplin kinerja guru dalam melaksanakan tugasnya di sekolah. Disiplin guru merupakan aspek terpenting dalam pengembangan sumber daya manusia yang ada. Oleh karena itu, disiplin sangat dibutuhkan agar tidak ada penyimpangan dan kelalaian yang dilakukan oleh guru di sekolah tersebut. Masalah penerapan disiplin kinerja guru bukan suatu hal yang mudah dilakukan oleh seorang kepala sekolah, akan tetapi merupakan sebuah tanggung jawab besar. Disamping itu, disiplin sangatlah berkaitan dengan nilai tingkah laku seseorang, baik menyangkut pribadi maupun kelompok di suatu sekolah. Namun jika disiplin ini dikerjakan oleh guru dengan baik, maka tujuan yang akan dicapai dapat terealisasi, begitu juga sebaliknya. Apabila disiplin tersebut tidak sesuai dengan harapan yang diinginkan, maka tujuan yang dicapai tidak akan maksimal.

Kepala sekolah selaku leader tertinggi disebuah sekolah tentunya harus berperan aktif dalam mengatasi masalah di atas, karena kepala sekolah tidak hanya berperan sebagai kekuatan penggerak kehidupan sekolah, akan tetapi kepala sekolah harus mampu berperan dalam memahami tugas dan fungsi guru yang ada demi tercapainya keberhasilan sekolah yang akan dipimpinnya. Sebagaimana diketahui, dari hasil observasi terhadap kepemimpinan kepala sekolah di SDN 02 Josenan Kota Madiun. Jika dilhat dari segi pengawasan leader tampaknya masih kurang memberikan sanksi tegas terhadap guru yang melanggar aturan seperti keterlambatan dalam kehadiran dan meninggalkan sekolah sebelum waktunya. Mereka terkadang meninggalkan 
sekolah bila jam belajar mengajar mereka telah usai yang tidak sesuai dengan jam pelajaran yang telah ditetapkan oleh sekolah. Selain itu, mereka juga sering meminta bantuan-bantuan tenaga kependidikan yang ada di dalam menilai dan memeriksa setiap tugas-tugas yang diberikan kepada para peserta didik, sehingga kurangnya efektivitas dalam pencapaian organisasi sekolah secara tepat.

Berangkat dari uraian di atas, pentingnya peran kepala sebagai leader dalam mencapai keberhasilan dalam sebuah organisasi yang ada. Maka dengan hal itu, artikel ini akan berupaya menjawab bagaimana peran kepala sekolah sebagai leader dalam meningkatkan disiplin kinerja guru di SDN 02 Josenan Kota Madiun?

Jika kita mengacu kepada rumusan masalah yang akan dicapai, maka tujuan dari penelitian ini adalah untuk mengetahui peran kepala sekolah sebagai leader dalam meningkatkan disiplin kinerja guru di SDN 02 Josenan Kota Madiun. Penelitian ini nantinya akan bermanfaat dalam rangka meningkatkan disiplin kinerja guru dalam mewujudkan pembelajaran yang efektif dan efisien di sekolah.

Kepemimpinan ataupun leadership dapat diartikan sebagai pengaruh, seni atau proses yang mempengaruhi orang-orang sehingga mau berjuang, bekerja secara sukarela, dan juga penuh antusias untuk mencapai tujuan kelompok (Burhanuddin, 1994:61). Definisi tersebut senada dengan pendapat "Wahjosumidjo, (1998)" yang mengatakan bahwasanya kepemimpinan merupakan suatu kegiatan mempengaruhi orang lain untuk bekerja keras dengan penuh kemauan dan tanggung jawab dalam upaya mencapai tujuan kelompok yang ada Jadi segala macam bentuk kepemimpinan merupakan tanggungjawab terbesar bagi seorang leader di dalam memimpinnya. Kesalahan yang terdapat di dalam kepemimpinan akan berdampak buruk dan bahkan mengakibatkan gagalnya organisasi untuk menjalankan misinya (Hasibuan, 2001:167), oleh karenanya itu kepemimpinan sangat menentukan arah dan tujuan maupun proses pemberian bimbingan serta menciptakan iklim kinerja yang dapat mendukung pelaksanaan proses pendidikan secara keseluruhan. Istilah kepemimpinan sebagaimana disinggung sebelumnya mengacu dari kata pemimpin ataupun leader. Hasibuan mencoba untuk mengelompokan istilah leader kedalam dua point: Pertama, leader adalah seseorang yang menggunakan kewenangannya dan mengarahkan bawahan untuk mengerjakan sebagian pekerjaannya dalam mencapai suatu organisasi tertentu. Kedua, leader adalah orang yang memiliki sifat-sifat kepemimpinan dan memiliki kewibawaan (personality authority) Dengan demikian, pendapat di atas dapat ditarik benang merah bahwa leader merupakan orang yang memiliki sifat kepemimpinan yang menggunakan kewewenangannya untuk mengarahkan para bawahan melakukan suatu pekerjaan demi tercapainya tujuan organisasi.

Disisi lain, leader juga diartikan sebagai seseorang yang memiliki sebuah kecakapan dan keterampilan tertentu dapat mempengaruhi para pengikutnya bekerjasama dalam rangka mencapai tujuan yang telah ditetapkan. Menurut Koontz, adapun keterampilan yang harus dimiliki seorang leader dalam mencapai tujuan tersebut meliputi: a) otoritas pemimpin, b) kemampuan menyatukan human resources, c) mengembangkan iklim kerja, d) mengembangkan gaya-gaya kepemimpinan (Konntz, 1990:82). Keempat keterampilan tersebut harus dimiliki seorang leader dapat mencapai tujuan pendidikan. Disamping itu, ia dituntut juga untuk memiliki banyak kelebihan dan kecakapan dibandingkan anggota lainnya seperti kelebihan moral, semangat kerja, kecerdasan, keuletan, skill, dan sebagainya (Hanafiah, 2018:68-92). Sebagai seorang leader kepala sekolah harus mampu dalam memimpin, melaksanakan, mampu merencanakan, mengawasi hubungan antara anggota-anggota, memberi sanksi terhadap para pelanggar, menindak, dan bertanggung jawab terhadap apa yang dipimpinnya (Purwanto, 2002:65). Dengan demikian, adanya keterampilan dan kecakapan yang dimiliki, maka akan dapat meningkatkan kualitas kepemimpinan kepala sekolah menjadi lebih baik, berkompeten dan berdampak positif terhadap pelaksanaan proses pendidikan yang ada di sekolah.

Elsbree mengatakan bahwa kualitas kepemimpinan kepala sekolah harus mencakup empat aspek yang meliputi: a) personality; kepala sekolah yang efektif harus memelihara hubungan baik secara umum seperti memiliki sifat bersahabat terhadap orang lain, responsive, antusias, murah hati, spontan, percaya diri, bebas dari perasaan takut dan kebimbangan. b) purpose; kepala sekolah selaku pimpinan kelompok harus bisa memformulasikan tujuan organisasi dan menginformasikan kepada bawahannya untuk 
bekerjasama untuk mencapai tujuan. c) knowledge; kepala sekolah harus mempunyai otoritas, pengetahuan luas, dan keputusan tepat dan mantap. d) professional skill; kepala sekolah harus memiliki keterampilan profesional yang efektif dalam fungsi-fungsi administrasi pendidikan (Hidayati, 1999:67). Kualitas kepemimpinan di atas yang telah dimiliki kepala sekolah akan dapat berpengaruh baik terhadap kemajuan lembaga pendidikan, karena kualitas sangat dibutuhkan dalam upaya meningkatkan disiplin kinerja guru menjalankan tugas sebagai seorang pendidik.

Disiplin sebagaimana telah dikatakan oleh Mardiatmadja berasal dari kata "disipel" berarti pengikut yang telah sungguh-sungguh dan yakin dengan ketentuan ajaran-ajaran pimpinannya (Mardiatmadja, 1988). Sedangkan kinerja guru adalah sebuah istilah yang berasal dari kata "job performance/actud performance" berarti prestasi kerja atau prestasi sesungguhnya yang dicapai oleh seseorang. Pencapaian hasil kinerja tersebut dilakukan berdasarkan standar-standar dan alat ukur tertentu yang dibutuhkan dan keberhasilan kinerja sangat berkaitan dengan kepuasaan kerja seseorang (Usman, 2007:100). Jadi, Disiplin kinerja guru itu dapat diartikan sebagai ketaataan seorang guru terhadap ketentuan ajaran-ajaran pemimpinnya yang diperoleh berdasarkan standar dan alat ukur tertentu guna mencapai kepuasan kerjanya. Disiplin kinerja guru sangat berkaitan erat dengan kepemimpinan kepala sekolah, karena seorang kepala sekolah selaku leader harus mampu membantu guru dalam mengembangkan pola dan standar perilakunya serta melaksanakan aturan untuk meningkatkan disiplin kinerjanya.

Disisi lain, disiplin kinerja guru merupakan bagian/variabel terpenting dalam pengembangan manajemen sumber daya manusia, karena disiplin itu sebagai penunjang tercapai tujuan organisasi. Dengan kata lain, apabila para guru yang ada didalamnya tidak mengikuti peraturan yang telah berlaku, maka tujuan organisasi yang diinginkan sulit tercapai. Disamping itu, disiplin diperlukan agar tidak terjadi keteledoran, penyimpangan, dan kelalaian terhadap guru dalam melaksanakan tugas sebagai pendidik. Maka dengan demikian, disiplin tersebut bertujuan untuk mengubah tingkah laku guru agar tetap mentaati peraturan yang telah ditetapkan kepala sekolah, sehingga pada akhirnya guru memiliki disiplin dan loyalitas kerja yang tinggi, masuk tepat pada waktunya, dan pulang pada waktunya serta mentaati semua tata tertib yang telah berlaku.

Wether dan Davis sebagaimana dikutip Usman menyebutkan bahwa kinerja guru sangat dipengaruhi oleh beberapa faktor, diantaranya kemampuan (ability $=$ knowledge + skill), dan motivasi (motivation $=$ attitude + situation) (Ibid, 2007:74). Berdasarkan atas rumusan tersebut dikatakan bahwa kinerja guru adalah unjuk kerja yang ditunjukan oleh guru baik secara kualitas maupun kuantitasnya. Faktor kemampuan sangat membantu hasil perpaduan antara kecakapan dengan motivasi, dimana masing-masing tersebut variabelnya dihasilkan dari sejumlah faktor lain yang saling mempengaruhi satu dengan lainnya dalam melakukan pekerjaannya sesuai tugas dan tanggung jawab yang diembankan kepadanya. Pendapat Wether dan Davis di atas senada dengan pernyataan Hasibuan yang dikutip Suhardiman bahwa hasil suatu kinerja yang dicapai oleh seseorang dalam menjalankan tugas-tugas yang dibebankan kepadanya dapat didasarkan pada kecakapan, pengalaman, kesungguhan, dan waktu (Suhardiman, 2012:126). Dengan demikian, demi tercapai hasil kinerjanya maka seorang guru harus mampu memenuhi dua hal, diantaranya memiliki kapabilitas dan loyalitas. Kapabilitas yakni guru harus memiliki kemampuan dalam bidang ilmu yang akan diajarkannya kepada peserta didik, dan memiliki kemampuan teoritik tentang berbagai cara mengajar yang baik mulai dari perencanaan, implementasi hingga pada evaluasi pembelajaran. Sementara loyalitas adalah seorang guru loyal terhadap tugastugas keguruannya, tidak semata hanya berada di dalam kelas, akan tetapi juga di luar kelas.

Sebagaimana telah disinggung sebelumnya, dalam upaya untuk mengetahui hasil kinerja atau prestasi seorang guru dalam menjalankan tugas dan tanggung jawabnya dalam proses belajar mengajar, maka dibutuhkan alat ukur yang sesuai dengan standar-standar tertentu supaya dapat memperoleh hasil kinerja atau prestasi yang dicapai. Oleh karena itu, hasil kinerja atau prestasi guru hanya dapat diketahui dengan melakukan penilaian atas kinerjanya. Penilaian kinerja pada dasarnya merupakan salah satu faktor kunci untuk mengembangkan suatu organisasi secara efektif dan efisien. Untuk keperluan terhadap penilaian kinerja guru, maka dibutuhkan adanya informasi yang berkualitas dan juga valid sehingga mampu 
menggambarkan kinerja guru secara baik serta diperlukan suatu perencanaan yang lebih mantap bagi karier mereka masing-masing kelak. Dengan demikian, dapat ditarik benang merah bahwa penggambaran dan perencanaan tepat terhadap penilaian kinerja guru akan dapat memperoleh hasil baik bagi kedisiplinan kinerja guru dalam menjalankan tugas dan fungsinya sebagai seorang pendidik.

Menurut "Fattah, 2009" guru yang bermutu dapat dilakukan penilaian kinerja yang mencakup lima faktor utama diantaranya: 1) kemampuan profesional, kemampuan intelegensi, sikap dan prestasi dalam bekerjanya; 2) upaya profesional, seorang guru mentransformasikan kemampuan profesionalnya dalam proses belajar-mengajar; 3) ketepatan waktu yang diberikan untuk kegiatan profesional, yakni intensitas waktu seorang guru di dalam menjalankan tugas profesionalnya; 4) kesesuaian waktu dicurahkan untuk kegiatan profesional, yakni guru haruslah mendukung proses belajar mengajar sampai tuntas dan benar; dan 5) kesejahteraan diberikan kepada guru harus memadai (Usman, 2007:105). Dengan demikian, maka penulis simpulkan bahwa pendapat di atas itu menjelaskan kinerja guruguru bisa dilakukan dengan berbagai macam cara. Jika tidak menutup kemungkinan mutu guru-guru yang ada dapat meningkat begitu profesionalisme yang ada akan semakin baik dan juga lebih mantap.

\section{METODE PENELITIAN}

Penelitian ini merupakan studi kasus menggunakan pendekatan kualitatif yang berfokus kepada peran kepala sekolah sebagai leader dalam meningkatkan disiplin kinerja guru di SDN 02 Josenan Kota Madiun. Teknik pengumpulan data adalah observasi dan wawancara secara langsung dengan kepala sekolah. Adapun teknik analisis data yang digunakan dengan mereduksi data, display data, dan mengambil kesimpulan dari data yang telah terkumpul (Miles dan Huberman, 1992: 91-93). Reduksi data dilakukan dengan cara proses pemilihan, pemuatan perhatian kepada penyederhanaan atau peningkatan data dalam bentuk uraian atau laporan terperinci. Display data berupaya menyajikan data itu dengan cara melihat gambaran keseluruhan atau bagian tertentu dari data penelitian untuk mempermudah di dalam membaca data, maka data yang telah direduksi selanjutnya akan disajikan dengan cara menggabungkan informasi yang tersusun di dalam satu bentuk yang mudah dilihat untuk dan dilakukan kajian. Dan mengambil kesimpulan guna mencari makna terhadap data yang dikumpulkan dengan cara mempelajari pola, persamaan, tema, perbedaan, dan hal yang paling banyak timbul.

\section{HASIL \& PEMBAHASAN}

\section{HASIL}

Gambar 1. Peran Kepala Sekolah Sebagai Leader di SDN 02 Josenan Kota Madiun

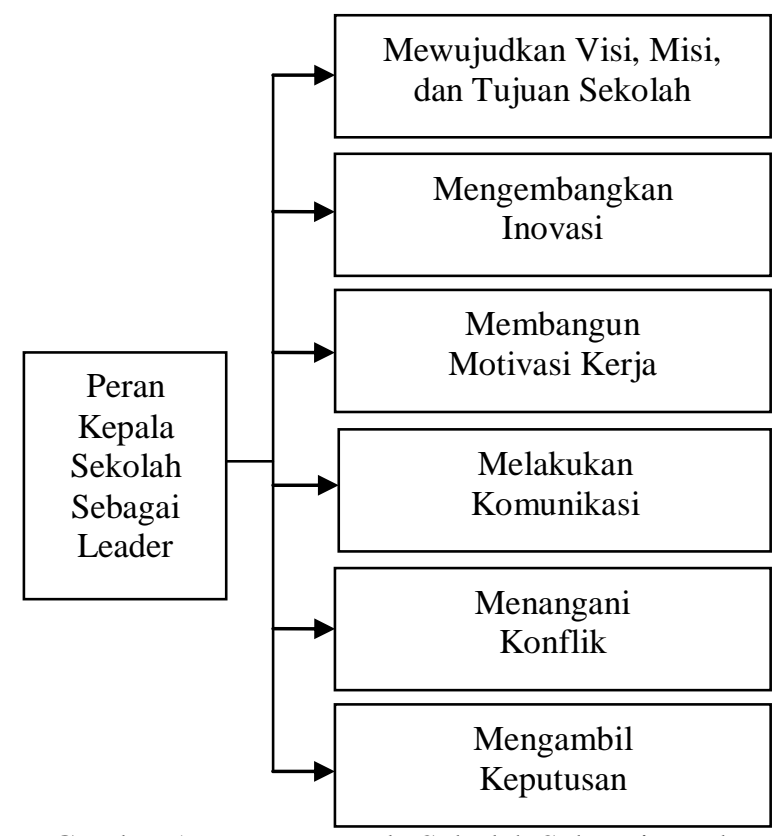

Gambar 1. . Peran Kepala Sekolah Sebagai Leader di SDN 02 Josenan Kota Madiun

Berdasarkan gambar di atas, maka dapat diperoleh hasil bahwa peran kepala sekolah sebagai seorang leader dalam meningkatkan mutu pendidikan di SDN 02 Josenan meliputi: mewujudkan visi, misi, dan tujuan sekolah. Untuk dapat mencapai sebuah visi, misi, maupun tujuan sekolah itu, kepala sekolah sebagai leader harus mampu meningkatkan kinerja guru dalam menjalankan tugasnya. Di dalam upaya meningkatkan disiplin kinerja guru di SDN 02 Josenan Kota Madiun, maka kepala sekolah sebagai leader harus memulainya dengan mewujudkan visi, misi, dan tujuan sekolah. Sebagaimana hasil dari observasi di lapangan menunjukkan bahwa visi SDN 02 Josenan Kota Madiun diantara lain menciptakan para peserta didik berprestasi, berbudi pekerti luhur, bertaqwa kepada Tuhan yang maha esa, berperan aktif di dalam menjaga maupun melestarikan lingkungan hidup serta siap menghadapi perubahan zaman. Sedangkan misinya yaitu upaya untuk meningkatkan mutu pendidikan 
melalui pembelajaran maupun bimbingan baik secara aktif, kreatif, dan menyenangkan; membiasakan berperilaku sopan santun dalam bergaul baik di rumah, sekolah, dan masyarakat; implementasikan ajaran agama yang dianut dalam kehidupan sehari-harinya; membudayakan disiplin; berbudi pekerti luhur, kerja keras, dan berjiwa sosial; membiasakan menjaga kebersihan diri, lingkungan sekolah dan lingkungan masyarakat; membudayakan menanam dan merawat tanaman baik di sekolah maupun di rumah; menciptakan lingkungan sekolah yang hijau maupun asri; membudayakan hemat energi dan sumber daya alam; dan mengenalkan dasar-dasar teknologi informasi. Dan tujuan sekolah yang akan dicapai mengacu pada tujuan pendidikan nasional yaitu mengembangkan potensi peserta didik agar menjadi manusia yang beriman dan bertaqwa kepada Tuhan yang maha esa, berakhlak mulia, sehat, berilmu, cakap, kreatif, mandiri, mampu menjadi warga negara yang demokratis dan juga bertanggung jawab. Disamping itu, tujuan SDN 02 Josenan Kota Madiun yaitu upaya meletakkan dasar kecerdasan, pengetahuan kepribadian, akhlak mulia, dan berketerampilan untuk hidup mandiri serta mengikuti pendidikan lebih lanjut.

Hasil wawancara dengan kepala SDN 02 Josenan Kota Madiun dalam rangka mewujudkan visi, misi, maupun tujuan sekolah, sebagai leader kepala sekolah harus mampu mempengaruhi guru-guru untuk selalu bekerja sama dan berperan aktif disetiap kegiatan sekolah. Salah satunya kegiatan dilakukan oleh kepala sekolah adalah menerapkan pembacaan visi, misi, dan tujuan sekolah pada saat literasi pagi setiap hari jum'at. Hal tersebut bertujuan agar seluruh komponen-komponen yang ada dilembaga seperti guru, karyawan, maupun siswa dapat memahami visi, misi, maupun tujuan sekolah yang dicapai. Pada kegiatan pembacaan literasi tersebut dilakukan secara berkelanjutan dan konsisten yang nantinya akan berdampak positif dan lama-kelamaan semua guru, karyawan, dan siswa menjadi hafal. Terlepas dari itu, dalam pembiasaan terhadap pembacaan literasi ini, guru dan karyawan sebagai elemen paling utama sekolah diharapkan bisa menerapkan dengan baik dari visi, misi, dan tujuan sekolah yang telah dibuat. Agar tercapai dengan baik, kepala sekolah selaku leader harus selalu melakukan pengawasan dan bimbingan secara konsisten bagi pelaksanaan pembiasaan literasi itu.
Kepala SDN 02 Josenan Kota Madiun selain berperan aktif melancarkan kegiatan sekolah, ia juga memberikan motivasi terhadap para siswa agar mampu menerapkan visi, misi, maupun tujuan sekolah di dalam kegiatan pembelajaran yang ada. Sebuah visi, misi, dan tujuan sekolah tidak dapat tercapai jika kepala sekolah tidak bekerja keras dalam membangun hubungan yang baik dikalangan guru, karyawan, dan siswa sehingga dapat terealisasi sesuai dengan harapan terhadap program sekolah kedepannya.

Peran kepala sekolah yang kedua adalah mengembangkan inovasi. Sebagaimana dari hasil wawancara secara langsung dengan kepala SDN 02 Josenan Kota Madiun, upaya yang dilakukan dalam rangka mengembangkan inovasi yang berkaitan dengan pendisiplinan kinerja guru, selaku steackholder tertinggi dilembaga tersebut harus memiliki strategi yang tepat dan akurat mencapai tujuan tersebut. Beberapa usaha yang dapat dilakukan kepala sekolah diantaranya yaitu: 1) selalu menjalin hubungan harmonis dengan lingkungan, baik dengan guru, karyawan, bahkan kepada para siswa; 2) mencari dan menciptakan ide atau gagasan terbaru yang belum pernah dilakukan dilembaga tersebut; 3) menjadi teladan kepada seluruh guru dan karyawan agar mereka dapat secara terusmenerus mengembangkan model-model pembelajaran inovatif; 4) kepala sekolah harus mampu memberikan petunjuk, arahan, maupun pegawasan ke seluruh elemen lembaga yang ada sehingga dapat membantu dalam meningkatkan inovasi kepada guru maupun karyawan; 5) mampu melakukan dan membangun komunikasi dua arah, baik secara vertikal yaitu antara kepala sekolah dengan guru, dan karyawan serta secara horizontal antara sesama guru dan karyawan. Hal tersebut dilakukan agar terciptanya keharmonisan diantara kepala sekolah, guru, karyawan dan siswa sehingga dapat melakukan kerjasama dalam mencapai tujuan. Disamping itu, agar dapat mempermudah kepala sekolah apabila memiliki tugas dan kegiatan yang berbenturan sehingga ia dapat mendelegasikan tugas tersebut kepada guru, dan karyawan.

Dilain pihak kepala SDN 02 Josenan Kota Madiun juga mengatakan bahwa inovasi tersebut merupakan suatu hal terpenting bagi kemajuan suatu sekolah, maka selaku leader di sekolah harus bisa melakukan inovasi secara berkelanjutan dan sebaik-baik mungkin agar tidak mengalami penurunan terhadap perkembangan lembaga yang ada. Dalam 
mengembangkan inovasi dilembaga SDN 02 Josenan Kota Madiun, kepala sekolah berupaya memberikan penjelasan kepada seluruh guru untuk selalu menambahkan nilainilai berinovasi di dalam proses pembelajaran, karena jika guru mengajar dengan inovatif maka ia dapat menjadi suri teladan maupun contoh yang baik bagi siswanya sehingga pada akhirnya siswa mampu berinovasi dan berkreatifitas sesuai tingkat kemampuannya mereka masing-masing. Namun tidak lepas dari itu saja, kepala sekolah harus bisa memberikan contoh kinerja yang penuh dengan inovasi terhadap bawahannya dan mengingatkan kepada seluruh guru dan karyawan bahwa inovasi itu sangat penting untuk kemajuan sekolah serta mendukung setiap inovasi yang dilakukan oleh semua elemen sekolah yang ada. Ini dilakukan karena kebanyakan guru-guru di lembaga SDN 02 Josenan Kota Madiun telah memasuki usia senja sehingga perannya sebagai guru sudah tidak terpikirkan untuk melakukan inovasiinovasi terhadap kemajuan lembaga baik berkaitan dengan proses pembelajaran dan lain sebagainya, akan tetapi mereka hanya terfokus pada mengajar saja.

Peran kepala sekolah ketiga adalah membangun motivasi kerja. Sebagaimana hasil dari wawancara dengan kepala SDN 02 Josenan Kota Madiun bahwa upaya seorang kepala sekolah dalam membangun motivasi kerja dapat dilakukan dengan menyisipkan motivasi semangat kerja tulus dan ikhlas ketika ada rapat berlangsung serta berbicara secara personal dengan guru dan karyawan sekolah lainnya. Selain itu, usaha lain dilakukan kepala sekolah dengan mengatur lingkungan fisik sekolah seperti mengatur suasana dan tempat kerja jadi kondusif, disiplin, dan memberikan reward atau penghargaan kepada guru, dan karyawan sekolah lainnya yang telah melaksanakan kinerjanya dengan baik agar yang lainnya dapat termotivasi dan terpacu untuk selalu semangat dalam bekerja guna mencapai keefektivitasan dan keefisienan dalam melaksanakan tugas dan tanggung jawabnya sebagai pendidik maupun tenaga kependidikan dilembaga tersebut. Dengan demikian, demi perbaikan dan kualitas pendidikan yang akan dicapai di lembaga tersebut, sebagai leader kepala sekolah harus mampu berusaha dengan semaksimal mungkin untuk mengembangkan motivasi kerja guru dan karyawan sekolah lainnya guna meningkatkan mutu pendidikan agar kelaknya lembaga tersebut dapat bersaing dengan lembaga pendidikan lainnya.

Peran kepala sekolah keempat adalah melakukan komunikasi. Sebagaimana hasil wawancara dengan kepala SDN 02 Josenan Kota Madiun, melakukan komunikasi itu merupakan hal yang paling utama demi kelancaran bagi keberlangsungan proses pembelajaran yang ada. Hal itu menjadi suatu dasar tercipta interaksi yang baik antara kepala sekolah dengan bawahannya yaitu guru dan seluruh karyawan sekolah. Itu menjadi suatu keharusan bagi seorang kepala sekolah guna melakukan komunikasi terhadap berbagai elemen yang ada. Dalam melakukan tindakan komunikasi tersebut, kepala sekolah melakukan upaya tegur sapa dengan para guru dan karyawan ketika bertemu di jalan dan di tempat manapun. Disamping itu, membangun komunikasi tersebut dapat juga dilakukan dengan menggelar rapat sehingga nantinya kepala sekolah selaku leader dapat mengetahui langsung keluh kesah yang dialami guru dan karyawan, serta mendengar langsung masukan dari guru dan karyawan terhadap berbagai masalah yang sedang mereka alami. Dan yang terpenting kepala sekolah dapat berbicara secara face to face kepada guru-guru agar mengerti apa yang sedang dihadapi mereka, karena dalam mencapai tujuan pendidikan yang ada pada suatu lembaga harus diperlukan kerjasama antara berbagai elemen, tidak hanya sebatas kepala sekolah sendiri. Dengan demikian bahwa upaya untuk membangun komunikasi itu sangat penting demi kelancaran seluruh komponen sekolah yang ada baik yang berkaitan dengan proses pembelajaran maupun lain sebagainya.

Peran kepala sekolah kelima adalah menangani konflik. Sebagaimana hasil di wawancara secara langsung kepada kepala SDN 02 Josenan Kota Madiun menunjukkan bahwa upaya yang dilakukan dalam menangani konflik-konflik diantara para guru, selaku kepala sekolah harus beinisiatif mengajak masing-masing pihak yang berkonflik untuk menyelesaikan masalah tersebut dengan cara bermusyawarah, atau istilah lain yaitu dengan cara kekeluargaan sehingga polemik yang terjadi dilembaga tersebut tidak melebar dan meluas keluar dan mencoreng nama baik sekolah. Sebelum mencari titik akar konflik yang terjadi diantara guru, selaku kepala sekolah terlebih dahulu memanggil pihak yang berkonflik secara individual sehingga mempermudah kepala sekolah dalam mencerna dan memahami akar permasalahan 
yang sedang dihadapi apabila dilakukan secara face to face. Kepala sekolah melakukan mediasi dengan cara mendengarkan masalah dari versi mereke masing-masing. Dalam hal ini kepala sekolah menjadi penengah terhadap kedua belah pihak yang sedang berkonflik untuk menemukan solusi tepat terhadap konflik yang sedang dihadapi oleh kedua belah pihak tersebut. Kemudian langkah selanjutnya kepala sekolah mendudukkan kedua belah pihak secara bersama-sama bermufakat untuk saling memaafkan satu sama lainnya. Terlepas dari itu semua, kepala sekolah harus memberikan sedikit nasehat dan motivasi agar kedepan tidak terjadi hal-hal yang seperti ini. Dengan demikian, maka peran kepala sekolah sebagai leader dalam menangani konflik yang ada telah terealisasi dengan baik sehingga ia dapat dikatakan telah berusaha menjalankan jiwa kepemimpinannya sebagai kepala sekolah untuk menyatukan para guru-guru maupun karyawan yang sedang bermasalah.

Peran kepala sekolah yang terakhir adalah mengambil keputusan. Sebagaimana hasil dari wawancara bersama dengan kepala sekolah, maka diketahui bahwa seorang kepala sekolah dalam mengambil sebuah keputusan terhadap perkara di SDN 02 Josenan Kota Madiun dilakukan dengan kepala dingin, tenang, tidak emosi, dan saling mengedepankan kepentingan bersama. Pertama kali kepala sekolah harus memikirkan sejenak perkara ataupun permasalahan yang ada supaya segera dapat menemukan solusi yang tepat bagi kepentingan bersama dan dapat diterima semua pihak. Selain itu, sebagai leader kepala sekolah harus melakukan musyawarah atau rapat dengan guru-guru dan karyawan yang ada sehingga ia dapat mendengarkan masukan atau saran yang positif terhadap masalah tersebut. Ini dilakukan kepala sekolah agar dapat terciptanya asas-asas kepentingan bersama diantara semua pihakpihak sekolah. Dengan demikian, sebuah perkara atau masalah yang sedang dihadapi tidak serta merta diputuskan secara sepihak oleh kepala sekolah, tetapi terlebih dahulu mengajak seluruh pihak bermusyawarah agar nantinya dapat menghasilkan keputusan tepat bagi kemajuan dan kepentingan sekolah untuk kedepannya.

\section{PEMBAHASAN}

Kepala Sekolah dalam Mewujudkan Visi, Misi, dan Tujuan Sekolah

Berdasarkan dari hasil penelitian terungkap bahwa keberhasilan kinerja kepala sekolah dalam mewujudkan visi, misi, maupun tujuan SDN 02 Josenan Kota Madiun dilakukan melalui upaya mempengaruhi guruguru untuk berperan aktif di setiap kegiatan yang ditelah rancang oleh sekolah. Kegiatan itu berupa pembacaan literasi setiap sekali dalam seminggu tepatnya pada hari jum'at. Proses pembacaan literasi itu dilakukan secara konsisten dan berkelanjutan berupaya untuk melatih, memotivasi dan memberikan pemahaman pada guru dan siswa untuk menerapkan visi, misi, dan tujuan sekolah dalam upayanya mencapai keberhasilan. Pendek kata, pembacaan literasi itu merupakan kunci utama dalam mewujudkan visi, misi, dan tujuan SDN 02 Josenan Kota Madiun. Disamping itu, pembacaan literasi tidak akan berjalan sebagaimana mestinya apabila tidak ada pihak pengawasan dan bimbingan dari kepala sekolah secara continue dan konsisten agar apa yang telah dibuat dan dirancang tersebut dapat berjalan sesuai dengan harapan bersama demi kemajuan lembaga tersebut.

Berdasarkan pendapat di atas maka dapat dikatakan bahwa keberhasilan kepala sekolah sebagai leader dalam mewujudkan visi, misi, dan tujuan sekolah tergantung pada upaya dirinya sebagai leader menerapkan pembacaan literasi jum'at sebagai bacaan wajib bagi guru, siswa, dan komponenkomponen pendidikan lainnya yang ada di lembaga tersebut sehingga mereka dapat hafal dan mampu untuk menerapkannya di dalam kehidupan sehari-hari ketika berada di sekolah. Kepala sekolah perlu memberikan punishment terhadap guru, dan siswa yang tidak mengikuti proses pembacaan literasi jum'at itu, sehingga mereka mendapatkan efek jera dan malu apabila tidak ikut serta pada kegiatan literasi yang diberlakukan tersebut. Upaya ini memang sedikit terlihat ekstrim, karena pembacaan literasi tersebut bukanlah faktor utama tugas seorang guru dalam mengemban amanahnya sebagai pendidik. Namun, apabila tidak dilakukan nantinya akan berdampak buruk dan bisa menghilangkan ciri khas SDN 02 Josenan Kota Madiun sebagai salah satu SDN yang menerapkan pembacaan literasi setiap hari jum'at. Oleh karena itu, upaya tersebut dilakukan agar sekolah tidak melepaskan icon ataupun ciri khasnya sebagai lembaga yang memegang teguh terhadap visi, misi, dan tujuan sekolah yang telah ada di awal pendirian lembaga tersebut. 


\section{Kepala Sekolah dalam Mengembangkan Inovasi}

Berdasarkan dari hasil penelitian yang telah dilakukan di SDN 02 Josenan Kota Madiun itu bahwa langkah-langkah yang harus ditempuh kepala sekolah dalam upaya mengembangkan inovasi di SDN 02 Josenan Kota Madiun yaitu kepala sekolah harus menjalin hubungan harmonis dengan guru, karyawan, dan siswa, kepala sekolah menciptakan ide ataupun gagasan terbaru, kepala sekolah menjadi teladan, kepala sekolah harus bisa memberikan petunjuk, arahan, serta pegawasan secara maksimal kepada seluruh elemen-elemen sekolah, maupun kepala sekolah juga membangun komunikasi dua arah baik secara vertikal maupun horizontal. Upaya yang dilakukan tersebut bertujuan agar dapat menciptakan kerjasama yang baik dengan sesama pihak sekolah dan bisa mencapai suatu tujuan pendidikan yang akan berorientasi pada kemajuan pengembangan sekolah untuk kedepannya.

Pengembangan inovasi dilakukan kepala sekolah di atas hakikatnya sesuai dengan tujuan pendidikan nasional. Hal tersebut sebagaimana di dalam Pasal 3 Undang-Undang Nomor 20 tahun 2003 bahwa pendidikan nasional itu berfungsi untuk mengembangkan kemampuan dan membentuk watak serta peradaban bangsa yang bermartabat dalam upayanya untuk dapat mencerdaskan kehidupan bangsa, bertujuan mengembangkan potensi peserta didik supaya menjadi manusia beriman dan bertakwa kepada Tuhan Yang Maha Esa, berakhlak mulia, sehat, berilmu, kreatif, cakap, mandiri, dan menjadi warga negara yang demokratis serta bertanggung jawab. Upaya di dalam mencapai suatu tujuan pendidikan yang diharapkan, tidak hanya dilakukan kepala sekolah dengan upaya mengembangkan kemampuan dan potensi dimiliki guru maupun pegawai sekolah lainnya, akan tetapi kepala sekolah juga harus mengembangkan inovasiinovasi yang ada agar terciptanya mutu pendidikan lebih baik.

Berdasarkan hal di atas, maka upaya untuk melakukan inovasi memang sangat dibutuhkan oleh lembaga pendidikan guna meningkatkan kualitas pendidikan supaya lembaga tersebut dapat bertahan dan juga diminati oleh banyak orang serta mampu untuk bersaing dengan lembaga pendidikan lainnya kedepannya. Upaya pengembangan inovasi oleh kepala SDN 02 Josenan Kota Madiun hanya berfokus kepada pelaku pendidikan saja, akan tetapi pada aspek lain yang belum terlihat seperti pengembangan terhadap kurikulum, media maupun alat pembelajaran, sarana prasarana dan lainnya. Oleh karena itu, selaku kepala sekolah sebaiknya mengupayakan pengembangan inovasi-inovasi secara keseluruhan terhadap komponen seluruh pendidikan yang ada di lembaga itu, karena kemajuan terhadap lembaga pendidikan tentunya sangatlah memerlukan timbal balik dan sikap saling ketergantungan di antara komponen satu dengan komponen pendidikan lainnya. Dengan demikian, proses pendidikan yang akan dijalankan pada lembaga tersebut akan tetap eksis bahkan dapat mencapai kemajuan yang lebih baik.

\section{Kepala Sekolah dalam Membangun Motivasi Kerja}

Upaya membangun motivasi kerja itu akan berdampak positif terhadap semua produktivitas organisasi dan dapat meningkatkan efektif dan efesiensi kerja terhadap para guru dan karyawan. Dengan motivasi kerja yang tinggi serta ditambah kemampuan guru dan karyawan memadai dapat memacu kinerja lembaga secara keseluruhan akan menjadi lebih maksimal. Berdasarkan dari hasil wawancara dengan kepala SDN 02 Josenan Kota Madiun bahwa upaya membangun motivasi kerja terhadap para guru dan karyawan sekolah lainnya dilakukan cara-cara sederhana seperti menyisipkan motivasi semangat kerja tulus dan ikhlas, selalu berbicara secara personal untuk mengingatkan, pentingnya sikap tanggung jawab didalam bekerja, mengatur tempat kerja dengan sebaik mungkin agar menjadi lebih nyaman dan kondusif, memberikan reward atau penghargaan bagi kinerjanya yang bagus sehingga membuat mereka terpacu maupun termotivasi untuk bisa melakukan kinerja yang baik. Sebagai seorang kepala sekolah sangat penting untuk diperhatikan di dalam membangun motivasi kerja agar dapat mudah mencapai keefektivitasan dan keefisienan bekerja, karena keefektivitas maupun keefisienan dalam bekerja akan dapat menghasilkan kualitas pendidikan terbaik bagi lembaga tersebut.

Berdasarkan pendapat di atas, selaku kepala sekolah sangat penting untuk melakukan motivasi kerja agar mereka bertanggung jawab terhadap tugas yang diamanahkan. Hal ini selaras dengan pernyataan Herzberg di dalam Robbins (2008) 
bahwa apabila ingin memotivasi bawahan untuk bekerja maka kepala sekolah harus menggunakan faktor-faktor motivator instrinsik yang terdiri dari tanggung jawab bekerja, pengakuan, dan bahkan pengembangan potensi diri yang mereka miliki sehingga mereka dapat berupaya bekerja dengan semaksimal mungkin mencapai hasil kinerja terbaik. Upaya itu sebenarnya lebih mengarahkan kepada guru maupun karyawan sekolah lainnya untuk selalu memegang teguh atas tanggung jawab yang diberikan, disamping itu juga sebagai upaya kepala sekolah dalam mengingatkan bahwa tanggung jawab dalam bekerja itu merupakan kunci keberhasilan terhadap kemajuan lembaga pendidikan yang ada. Hal senada juga dikatakan oleh Ivana Kundratova (2009) di dalam sebuah penelitiannya bahwasanya tanggung jawab akan berpengaruh terhadap motivasi kerja, artinya keberhasilan motivasi kerja itu akan dapat dicapai apabila orangorang yang diberi tanggung jawab dalam bekerja dapat memegang teguh amanahnya.

Mencermati hasil uraian pendapat di atas, penulis menyimpulkan bahwa upaya motivasi kerja sangat perlu untuk direalisasikan bagi guru-guru, maupun karyawan sekolah lainnya. Upaya tersebut oleh kepala sekolah tidak hanya sebagai peningkatan kualitas kinerja guru yang ada, akan tetapi juga menanamkan sikap tanggung jawab yang besar terhadap tugas yang telah diberikan. Disisi lain motivasi kerja yang ada akan dapat mengembangkan potensi diri yang dimiliki oleh mereka sehingga membuat mereka untuk terpacu dan termotivasi dalam melakukan kinerja yang terbaik dan berkualitas bagi lembaga pendidikan yang ada itu. Maka tidak menutup kemungkinan upaya membangun motivasi kerja yang dilakukan oleh kepala sekolah akan menjadikan sekolah lebih bermutu dan lebih diminati lagi oleh para peserta didik yang akan belajar didalamnya serta memberikan rasa nyaman dan tentram bagi guru maupun karyawan sekolah lainnya dalam bekerja.

\section{Kepala Sekolah dalam Melakukan Komunikasi}

Kepala sekolah sebagai leader dalam upaya meningkatkan disiplin kinerja guru tidak lepas juga dari tugasnya dalam melakukan komunikasi kepada guru, maupun karyawan sekolah lainnya. Karena kegiatan itu merupakan hal yang paling utama demi kelancaran proses pembelajaran. Berdasarkan dari hasil wawancara yang telah dilakukan dengan kepala SDN 02 Josenan Kota Madiun bahwa upaya melakukan komunikasi tersebut memulai dengan tegur sapa para guru dan karyawan sekolah lain ketika bertemu dimanapun, menggelar rapat sehingga bisa dapat mengetahui secara langsung keluh kesah yang dialami para guru dan karyawan sekolah. Dan yang terpenting selalu mendengar langsung masukan dari para guru maupun karyawan sekolah terhadap problem yang sedang mereka hadapi. Terakhir upaya lain yang harus dilakukan oleh kepala sekolah dengan berbicara face to face kepada guru dan karyawan sekolah agar dapat terjalin sikap saling memperdulikan satu dengan lainnya guna meningkatkan kerjasama di dalam mencapai tujuan pendidikan lembaga itu.

Pentingnya untuk diketahui bahwa kemampuan komunikasi merupakan faktor penentu terhadap kesuksesan pada setiap individu maupun organisasi. Jika mengacu pendapat kepala sekolah di atas, maka suatu organisasi yang ada di sekolah akan berjalan dengan lancar apabila seluruh elemen didalamnya dapat bekerjasama satu sama dengan lainnya dan juga membangun komunikasi yang baik, karena komunikasi adalah sarana terpenting dalam menjalin hubungan baik antara kepala sekolah, guru, dan karyawan sekolah lainnya. Hal ini selaras dengan pernyataan Griffith (2002) bahwa komunikasi sangatlah dibutuhkan dalam suatu organisasi (sekolah), karena efektivitas komunikasi yang dilakukan di antara berbagai elemen sekolah yang ada akan menentukan kesuksesan organisasi (sekolah) baik dalam jangka yang pendek dan dalam jangka panjang. Komunikasi itu ibaratnya nafas kehidupan bagi makhluk, makhluk hidup tanpa nafas akan mati. Begitu juga halnya dengan sekolah, suatu kepemimpinan kepala sekolah tidak akan berjalan dengan lancar dan bahkan bisa mati apabila tidak terjalin komunikasi baik antara elemen sekolah lainnya seperti guru dan karyawan sekolah yang ada, karena setiap elemen sekolah itu bergantungan satu sama lainnya untuk menjalankan tugas maupun tanggung jawab demi mencapai keberhasilan.

Berdasarkan dari pendapat di atas, penulis mencoba menyimpulkan bahwa sebagaimana yang dikatakan oleh Griffith itu sangat penting untuk dilakukan oleh kepala sekolah sebagai leader dalam upaya meningkatkan disiplin kinerja guru di sekolah. Komunikasi tersebut merupakan suatu bentuk pendekatan di dalam menjalin hubungan baik 
dan menjalin kerjasama dalam sebuah organisasi (sekolah). Oleh karena itu, kesuksesan sekolah sangatlah dipengaruhi kapabilitas dan kompetensi masing-masing elemen sekolah yang ada didalamnya baik guru, karyawan sekolah dan lain-lain dalam menjalin kerjasama tim untuk mencapai tujuan bersama. Hal itu tentu hanya bisa dilakukan dengan adanya komunikasi baik yang dibangun oleh kepala sekolah sebagai leader tertinggi dilembaga tersebut.

\section{Kepala Sekolah dalam Menangani Konflik}

Berdasarkan hasil dari wawancara bersama dengan kepala SDN 02 Josenan Kota Madiun bahwa di dalam menangani konflik diantara guru, selaku leader kepala sekolah melakukan beberapa alternatif-alternatif untuk meredam konflik tersebut. Pertama kepala sekolah memanggil pihak yang sedang berkonflik secara individual agar mengetahui akar permasalahan yang sedang dihadapi, selanjutnya kepala sekolah melakukan penyelesaian konflik tersebut dengan cara bermusyawarah ataupun secara kekeluargaan sehingga konflik itu tidak akan meluas hingga keluar sekolah, kepala sekolah harus melakukan mediasi terhadap masalah tersebut dengan mendengarkan versi mereka masingmasing, dan upaya lain yang dilakukan dengan mendudukkan mereka disuatu tempat secara bersama-sama untuk bermufakat saling memaafkan.

Berdasarkan dari pendapat di atas, upaya penanganan konflik baik diantara guruguru dan karyawan sekolah lainnya telah benar-benar dilakukan sesuai dengan prosedur yang baik. Mulai dari memanggil pihak yang berkonflik hingga melakukan mediasi guna mencari akar permasalahan yang hadapi oleh kedua belah pihak. Masalah konflik ini sebenarnya tidak bisa dipisahkan dari kehidupan manusia, baik dalam organisasi, keluarga, masyarakat, bahkan sekolah juga mengalami adanya konflik. Sebagaimana dikatakan Robert G. Owen (1987), konflik itu lahir dari tekanan-tekanan yang tidak bisa diterima oleh individu-individu dalam organisasi. Hal itu senada dengan apa yang dikatakan Winardi (1994), kemunculan konflik yang ada disebuah organisasi baik di sekolah dan organisasi lainnya disebabkan adanya ketidaksesuain paham atas pokok-pokok pikiran tertentu. Oleh karena itu, perlu sikap saling mengalah dan memahami antara satu dengan lainnya sehingga tidak terjadi konflik.
Menangani konflik bukan hal yang mudah dilakukan oleh kepala sekolah sebagai seorang leader. Meskipun demikian, tetap harus dilakukan demi kebaikan bersama dan juga sebagai upaya mencegah terjadi pertikaian yang berkelanjutan diantara guru. Itu dilakukan guna mengantisipasi dampak buruk yang berakibat dapat mencoreng nama baik sekolah. Oleh karena itu, penanganan yang telah dilakukan oleh kepala sekolah dalam menangani konflik itu perlu langkah selanjutnya yaitu dengan memberikan nasehat dan motivasi kepada guru agar kedepan tidak melakukan hal-hal yang seperti di atas. Dengan demikian, penulis berpendapat bahwa upaya mendasar yang wajib dilakukan kepala sekolah di dalam menangani konflik di lembaga tersebut adalah bagaimana upayanya sebagai leader agar dapat meredam dan mencengah terjadinya konflik di lembaga yang sedang di pimpinnya, meskipun kenyataannya konflik tidak bisa dicegah dan dihindari.

\section{Kepala Sekolah dalam Mengambil Keputusan}

Pengambilan sebuah keputusan tidak

dapat dilakukan sebagaimana membalik telapak tangan, tetapi membutuhkan sebuah pemikiran matang. Hal itu dikarenakan keputusan itu pada gilirannya akan berdampak terhadap banyak aspek. Karena itu, untuk memperoleh sebuah keputusan akurat perlu pertimbangan agar kemungkinan timbulnya dampak negatif dari keputusan tersebut dapat diminimalisir. Sebagai kepala sekolah haruslah memperhatikan dan mempertimbangkan di dalam mengambil sebuah keputusan atas perkara yang sedang dihadapi guna mencegah terjadinya hal-hal yang tidak diinginkan. Berdasarkan hasil dari wawancara dengan kepala SDN 02 Josenan Kota Madiun, dalam mengambil keputusan sebagai leader kepala sekolah harus melakukannya dengan kepala dingin, tenang, tidak emosi, dan selalu mengedepankan kepentingan bersama. Sikap ini dilakukan kepala sekolah agar keputusan yang diambil dapat berdampak baik untuk seluruh elemen sekolah yang ada seperti guru, karyawan sekolah, bahkan pada siswa. Pendapat di atas selaras dengan pernyataan Terry dalam Marzuki (2015) bahwa selaku kepala sekolah harus benar-benar mengambil keputusan terbaik dari berbagai alternatif yang tersedia dan yang terpenting adalah menentukan mana putusan terbaik bagi organisasi dan para anggotanya demi kepentingan bersama didalam suatu organisasi. 
Upaya pengambilan keputusan dilakukan kepala SDN 02 Josenan Kota Madiun juga dengan memikirkan sejenak perkara atau permasalahan yang ada guna menemukan solusi tepat yang bisa diterima oleh semua pihak sekolah. Pendapat ini menunjukkan bahwa kepala sekolah tersebut tidak serta mengambil keputusan dengan semaunya saja tanpa bahan pertimbangan dari pihak-pihak lain. Pernyataan tersebut senada dengan Herbart A. Simon di dalam Asnawir (2006) bahwa sebagai kepala sekolah harus melakukan tiga tahapan yang wajib ditempuh dalam pengambilan keputusan meliputi tahap penyelidikan, tahap perancangan, dan tahap pemilihan. Hal itu selaras juga dengan pendapat Marzuki (2015) dalam penelitiannya menunjukkan bahwa pengambilan keputusan oleh kepala sekolah yang dilakukan melalui kegiatan identifikasi awal terhadap masalah, merumuskan tujuan, alternatif solusi, dan menentukan kriteria pemilihan solusi hingga menemukan solusi yang tepat untuk mendapatkan sebuah keputusan terbaik.

Berangkat dari berbagai pendapat yang ada, sebenarnya kepala sekolah selaku leader telah melakukan berbagai upaya dalam pengambilan keputusan tersebut, akan tetapi belum menemukan hasil maksimal. Maka dari itu, selanjutnya kepala sekolah akan melakukan musyawarah dengan guru maupuan karyawan sekolah agar dapat mendengarkan masukan dan saran yang positif terhadap perkara tersebut. Pengambilan keputusan secara musyawarah dilakukan oleh kepala sekolah dengan berupaya menegakkan sikap kepentingan bersama, karena sikap bermusyawarah merupakan suatu bentuk penghargaan terhadap orang lain. Disamping itu, keputusan yang diambil dengan bermusyawarah akan dapat diterima dan dapat dijalankan oleh seluruh pihak-pihak yang ada disebabkan didalamnya itu terdapat nilai-nilai kebajikan yang sangat tepat apabila diterapkan di dunia pendidikan.

Berdasarkan dari pendapat di atas, penulis menyimpulkan bahwa upaya dalam pengambilan keputusan tidak serta merta dapat dilakukan secara sepihak oleh kepala sekolah selaku leader tertinggi di lembaga pendidikan akan tetapi pihak-pihak lain yang terdapat didalamnya seperti guru, karyawan sekolah juga harus ikutsertakan di dalam proses pengambilan keputusan tersebut. Karena pengambilan keputusan yang terbaik nantinya akan berpengaruh terhadap kualitas pendidikan dan kinerja guru-guru serta karyawan sekolah.
Hal ini senada di dalam penelitiannya Budiono (2014) tentang ada pengaruh komunikasi organisasi, kecerdasan emosi, dan pengambilan keputusan terhadap implementasi peran kepemimpinan kepala sekolah dasar. penelitian tersebut menjelaskan bahwa di dalam pengambilan keputusan memiliki pengaruh yang positif dan signifikan terhadap implementasi peran kepemimpinan kepala sekolah. Dengan kata lain, adanya pengambilan keputusan dapat mempengaruhi kinerja seseorang dalam suatu sekolah. Dengan demikian, berdasarkan pernyataan yang ada dapat diambil benang merah bahwa pengambilan keputusan sangatlah dapat menentukan terhadap kinerja guru yang ada dilembaga pendidikan.

\section{KESIMPULAN \& SARAN}

Disiplin kinerja seorang guru sangat diperlukan di dalam proses meningkatkan mutu pendidikan di sekolah, karena kinerja guru berkaitan dengan proses pembelajaran yang akan diterima nantinya oleh peserta didik. Kepala sekolah sebagai seorang leader harus mampu dalam menerapkan kedisiplinan kinerja pada guru agar hasil pendidikan yang diperoleh peserta didik dapat tercapai dengan baik. Pentingnya disiplin kinerja guru tentu akan berdampak terhadap mutu pendidikan yang ada, mutu yang baik tidak akan dicapai apabila masih banyak dikalangan guru-guru tidak disiplin menjalankan tugas dan tanggungjawabnya sebagai seorang pendidik. Oleh karena itu, perlu perhatian cukup besar bagi kepala sekolah dalam menerapkan dan mengawasi tugas dan kinerja yang telah diembankan kepada guru. Hal ini semata-mata hanya ingin meningkatkan disiplin kinerja guna mencapai mutu pendidikan yang lebih baik.

Kepala sekolah sebagai seorang leader di lembaga pendidikan dalam upaya menyikapi masalah disiplin kinerja guru yang ada tentunya melakukan strategi atau langkahlangkah demi tercapainya tujuan pendidikan yang harapkan. Adapun langkah utamanya adalah mewujudkan visi, misi, maupun tujuan sekolah. Hal ini penting untuk dilakukan untuk mengetahui ke mana arah dan tujuan pendidikan yang akan dibawa. Selanjutnya kepala sekolah harus mengembangkan berbagai inovasi-inovasi pendidikan di lembaga tersebut untuk dapat meningkatkan kualitas pendidikan menjadi lebih baik sehingga proses dan hasil yang didapatkan akan berdampak lebih baik bagi peserta didik. 
Selain itu kepala sekolah juga harus membangun motivasi kerja bagi guru sehingga ia termovitasi untuk bekerja lebih giat dan bertanggung jawab lagi terhadap pekerjaannya. Disamping langkah-langkah di atas, kepala sekolah perlu melakukan komunikasi baik secara vertikal maupun horizontal guna mengetahui kesulitan atau masalah yang sedang dihadapi guru ketika melakukan pekerjaannya sebagai pendidik. Upaya itu nantinya akan mempermudah ia dalam menyelesaikan suatu masalah apabila terdapat konflik dikalangan para guru maupun pegawai sekolah lainnya, sehingga upaya menangani konflik itu merupakan perannya sebagai seorang leader. Adapun langkah terakhir bagi kepala sekolah adalah mengambil keputusan yang tepat terhadap perkara-perkara yang terjadi di lembaga pendidikan guna memperoleh keputusan terbaik bagi bersama.

Dengan demikian, maka keberhasilan terhadap peningkatan disiplin kinerja guru di atas tidak lepas dari keberhasilan kepala sekolah sebagai leader di dalam upayanya menjalankan langkah-langkah yang ada itu secara tepat dan sesuai dengan yang telah ditentukan. Untuk itu, terhadap kepala sekolah hendaknya selalu memahami lebih baik perannya sebagai leader dalam upaya meningkatkan disiplin kinerja guru, karena kinerja guru adalah bagian penting mencapai kesuksesan dan keberhasilan pendidikan khususnya dalam proses pembelajaran bagi peserta didik. Disamping itu, kinerja guru akan berdampak terhadap kualitas pendidikan yang akan dicapai oleh lembaga, maka pentingnya pengawasan terhadap kinerja guru tersebut agar hasil pendidikan yang diperoleh menjadi lebih baik dan sesuai dengan harapan bersama serta dapat menjadi bahan pertimbangan sebagai acuan bagi lembaga pendidikan yang lainnya.

\section{DAFTAR PUSTAKA}

Asnawir. (2006). Manajemen Pendidikan. Padang: IAIN Imam Bonjol Press.

Budiono. (2014). Pengaruh Komunikasi Organisasi, Kecerdasan Emosi dan Pengambilan Keputusan terhadap Implementasi Peran Kepemimpinan Kepala SD. Jurnal Akuntabilitas Manajemen 2(2), 147-158.

Burhanuddin. (1994). Analisis Administrasi Manajemen dan Kepemimpinan. Jakarta: Bumi Aksara.
Fattah, N. (2009). Ekonomi dan Biaya Pendidikan. Bandung: Remaja Rosdakarya.

Griffith, D. A. (2002). The Role of Communication Competencies in Internatioanl Bussiness Relationship Development. Journal of World Business 37(4), 256-265.

Hanafiah, M. A. (2018). Kepala Sekolah Sebagai Pemimpin dan Supervisor. Jurnal Al-Hikmah 15(1), 68-92.

Hasibuan, M. (2001). Manajemen Sumber Daya Manusia. Jakarta: Bumi Aksara.

Hidayati. (1999). Kepemimpinan Perempuan Kepala Sekolah dalam Konteks Pengajaran. Malang: PPS-UNM.

Konntz. (1990). Manajemen, Terjemahan Hutahurug. G. Jakarta: Erlangga.

Kundratova, I. (2009). Motivating Sosial Workers: The Significant Faktors Affecting Practical Sosial Work. Institute of Educology and Social Work, Fakulty of Arts, University of Presov.

Mardiatmadja, B. S. (1998). Disiplin. Jakarta: Kompas.

Marzuki. (2015). Pengambilan Keputusan Sekolah Melalui Manajemen Strategik Pada SMP. Jurnal Magister Administrasi Pendidikan USK 3(3), 5864.

Miles \& Huberman. (1992). Analisis Data Kualitatif terj. Cecep Rohedi Rosidi. Jakarta: Universitas Indonesia.

Owen, R. G. (1987). Organizational Behavior in Education. New Jersey: PrentionHall, Inc, Englawood Cliffs.

Purwanto, N. (2002). Administrasi dan Supervisi Pendidikan. Bandung: PT. Rosdakarya.

Robbins, Stephen, \& Judge, T. A. (2008). Perilaku Organisasi. Jakarta: Salemba Empat.

Suhardiman, B. (2012). Studi Pengembangan Kepala Sekolah. Jakarta: Rineka Cipta.

Usman, N. (2007). Manajemen Peningkatan Kinerja Guru. Bandung: Mutiara Ilmu.

Wahjosumidjo. (1998). Kepemimpinan dan Motivasi. Jakarta: Ghalilea Indonesia.

Winardi. (1994). Manajemen Konflik: Konflik Perubahan dan Pengembangan. Bandung: Bandar Maju 